\title{
Changes in the olfactory mucosa of the black bullhead Ictalurus melas induced by exposure to sublethal concentrations of sodium dodecylbenzene sulphonate
}

\author{
Cristina Zeni* ${ }^{*}$ Annamaria Stagni
}

Department of Biology, Section of Comparative Anatomy, University of Ferrara Via Luigi Borsari 46, 44100 Ferrara, Italy

\begin{abstract}
The effects of exposure to sublethal concentrations (1.5 and $3 \mathrm{mg} \mathrm{l}^{-1}$ ) of sodium dodecylbenzene sulphonate on the olfactory epithelium of Ictalurus melas Rafinesque were examined by light and scanning electron microscopy. The detergent affected the superficial part of each olfactory lamella and different morphological alterations, depending on dose and duration of treatment, were observed. The histology and surface morphology of sensory and non-sensory areas of the epithelium of fish treated with $1.5 \mathrm{mg} \mathrm{l}^{-1}$ for 5 and $10 \mathrm{~d}$ were not affected by the treatment, while only an incipient thinning-out of the long cilia of non-sensory epithelium was seen in fish treated for $15 \mathrm{~d}$. Treatment with $3 \mathrm{mg} \mathrm{l}^{-1}$ caused morphological alterations, related to the time of exposure, in the non-sensory and sensory epithelium, consisting of progressive thinning of cellular projections; this treatment also increased mucus production. These observed histopathological changes in the olfactory mucosa may modify the olfactory perception of the fish, and could thereby impair important physiological functions such as feeding, social interactions or migration.
\end{abstract}

KEY WORDS: Anionic detergent $\cdot$ Morphological changes $\cdot$ Ictalurus melas $\cdot$ LAS $\cdot$ Olfactory mucosa Scanning electron microscopy $\cdot$ Sodium dodecylbenzene sulphonate

Resale or republication not permitted without written consent of the publisher

\section{INTRODUCTION}

The introduction of synthetic chemicals into aquatic habitats is an important aspect of pollution, especially when their degradation is slow. Surfactants are crucially involved, on account of their large-scale use and their wide range of ecotoxicological effects. Linear alkylbenzene sulphonates (LAS) comprise the majority of anionic surfactants currently employed in the detergent industry worldwide, justified by their greater biodegradability compared to other types of detergents (Gledhill 1974, Gard-Terech \& Palla 1986, Schoenkaes 1998, Scott \& Jones 2000). Their environmental occurrence arises mainly from domestic and industrial effluents.

Most morphological studies on pathology induced by major environmental toxicants (organochlorine and polyaromatic hydrocarbons) in teleosts has been

*E-mail: zen@dns.unife.it carried out on the liver (Klaunig et al. 1979, Hawkins et al. 1990, Braunbeck et al. 1992, Arnold et al. 1996, Hinton \& Couch 1998), a crucial organ in metabolism, and the main site of activity of cytochrome P4501A1 isoform (CYP1A1: Braunbeck \& Volkl 1991, Lester et al. 1993, Goksoyr \& Husoy 1998, Sarasquete \& Segner 2000). Various water-borne xenobiotics induce ex novo synthesis of the enzymatic system in fishes, while in teleost CYP1A1 has been immunolocalized also in extrahepatic systems, including the olfactory organs (Smolowitz et al. 1992, Monod et al. 1995). Saucier et al. (1999) have recently shown that, in untreated fishes, CYP1A1 is constitutively expressed in non-sensory epithelium. After induction, CYP1A1 increases its activity in the non-sensory epithelium, and is additionally expressed in the sensory epithelium.

The histopathological alterations induced by detergents in fishes have been studied mostly in the gills (Mallatt 1985, Misra et al. 1985, Roy 1988b, Ribelles 
et al. 1995a), but also in the epidermis (Pohla-Gubo \& Adam 1982, Garg \& Mittal 1993, Mittal \& Garg 1994), liver, spleen, kidney, pancreas, intestine (Ribelles et al. 1995b,c, Rosety et al. 1997), erythrocytes (Zeni et al. 2002) and chemosensory organs (taste buds and olfactory organs: Bardach et al. 1965, Cancalon 1983, Zeni \& Stagni Caligiuri 1992, Zeni et al. 1995, Pareschi et al. 1997). With regard to the morphological alterations induced in olfactory neurons by other environmental pollutants, most of the available data concern neurotoxic heavy metals (Gardner 1975, Cancalon 1982, Klaprat et al. 1988, Baatrup \& Døving 1990, Julliard et al. 1993, 1996, Oliveira Ribeiro et al. 1995, Hansen et al. 1999b).

Because of its external nature, fish olfactory mucosa is a suitable target for environmental studies. Fishes depend on intact sense organs for discriminating a wide array of odorous molecules involved in survivallinked behaviours (i.e. searching for food, intra- and interspecific interactions, defence against predators, migration, reproduction and parental care: Døving 1986, Hara 1994). Behavioural tests performed on fishes after removal of their olfactory organs have shown that their avoidance reaction to pollutants depends mainly on olfactory stimuli (Hidaka \& Tatsukawa 1989). Teleost species of the family Ictaluridae have frequently been used for morphological (Caprio \& Raderman-Little 1978, Theisen et al. 1991, Zeiske et al. 1994), and biochemical, physiological and behavioural studies (Goulding et al. 1992, Restrepo 1993, Valentincic \& Caprio 1994, Abogadie et al. 1995) on olfaction. Only 1 study has documented the morphological alterations induced by a non-ionic detergent (Triton X-100) on Ictalurus punctatus olfactory mucosa (Cancalon 1983).

The aim of the present study was to evaluate, by light and scanning electron microscopy, the morphological changes induced in the olfactory epithelium of Ictalurus melas by 2 sublethal concentrations of the anionic detergent Na-dodecylbenzene sulphonate (LAS). The doses employed were close to the maximum concentrations allowed in effluents $\left(\leq 2 \mathrm{mg} \mathrm{l}^{-1}\right.$ for superficial waters, $\leq 4 \mathrm{mg} \mathrm{l}^{-1}$ for sewage: directive EEC 91/271 on Water Quality, Italian Official Gazette no./24 29/5/99 L. 152).

\section{MATERIALS AND METHODS}

Fish. Juvenile specimens of the black bullhead Ictalurus melas Rafinesque (length 14 to $19 \mathrm{~cm}$, weight 65 to $95 \mathrm{~g}$ ) were obtained from a local hatchery and acclimatized to laboratory conditions for $15 \mathrm{~d}$ before the experiment. The study was carried out in aquaria in a static system. The fish were kept in PVC tanks containing $200 \mathrm{l}$ of aerated and dechlorinated tap

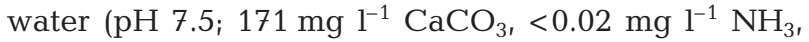
$<0.005 \mathrm{mg} \mathrm{l}^{-1} \mathrm{NO}_{2}^{-}, 6.9 \mathrm{mg} \mathrm{l}^{-1} \mathrm{NO}_{3}^{-} ; 19$ to $22^{\circ} \mathrm{C}$ ), and were fed daily (10 $\mathrm{g} \mathrm{kg}^{-1}$ body wt) with commercial dry pellets (SERA Viformo, Germany).

Treatments. Following acclimatization, the fish were divided into 3 experimental groups: a control group was maintained in detergent-free water, and the other 2 groups were exposed for $15 \mathrm{~d}$ to nominal concentrations of 1.5 or $3 \mathrm{mg} \mathrm{l}^{-1}$ of LAS. All experiments were conducted in a natural daylight regime. To maintain a constant LAS concentration (Zaccone 1985a, Rosety et al. 1997), water and detergent were renewed: control and treated specimens were transferred every $24 \mathrm{~h}$ to aquaria containing clear dechlorinated, aerated tap water, and LAS were added to the water containing the treated fish to the nominal concentrations. Previous determination of the LAS concentration using methylene blue-active substances under these experimental conditions had shown that degradation did not exceed $20 \%$ over $24 \mathrm{~h}$ (Zeni unpubl. data). The $\mathrm{LC}_{50}$ of ictalurids varies from 6.9 to $14.8 \mathrm{mg} \mathrm{l}^{-1}$ (Bardach et al. 1965, Zaccone et al. 1985a, Roy 1988a, Garg \& Mittal 1993). Sublethal pathological responses to LAS in the catfish Heteropneustes have been observed in the range 1.5 to $2.5 \mathrm{mg} \mathrm{l}^{-1}$ (Zaccone et al. 1985a,b), although values of no-observed effect and lowest-observed effect concentrations (NOECs, and LOECs) and $\mathrm{EC}_{50}$ for LAS in ictalurids are not yet available.

The olfactory rosettes were removed, under MS-222 (1:5000) anaesthesia, from some treated and control specimens after 5, 10, and $15 \mathrm{~d}$ of treatment. These were obtained by dissection of the nares; the fish were placed for at least $10 \mathrm{~min}$ in ice-cold water to decrease bleeding. All the fish were subsequently sacrified by an anaesthetic overdose.

Preparation of samples. The olfactory mucosa was examined by light and scanning electron microscopy (SEM). The olfactory organs were excised after 5, 10 and $15 \mathrm{~d}$ of treatment from the fish maintained in contaminated and control aquaria and accordingly processed. Some organs were fixed in Bouin's liquid (24 h, room temperature), dehydrated, and embedded in Paraplast (Sherwood-Medical, Ireland), and were used to prepare $7 \mu \mathrm{m}$-thick histological sections. These were mounted on slides and dried overnight. The slides were stained with Haematoxylin-Eosin (H\&E) and observed with a Leitz Dialux 20 microscope. Other olfactory organs were fixed $\left(3 \mathrm{~h}, 4^{\circ} \mathrm{C}\right)$ in $2.5 \%$ glutaraldehyde in $0.1 \mathrm{M}$ sodium phosphate buffer, $\mathrm{pH} 7.4$, rinsed in the buffer alone, postfixed $\left(1 \mathrm{~h}, 4^{\circ} \mathrm{C}\right)$ in $1 \% \mathrm{OsO}_{4}$ in buffer, and dehydrated in a graded series of ethanol. Once dehydration was complete, the olfactory rosettes were dried in a critical-point dryer (Balzers CPD 030) using $\mathrm{CO}_{2}$ as transitional fluid, and mounted on aluminium 
stubs with double-sided adhesive tape. The preparations were gold-sputtered (20 nm) under vacuum, using an Edwards S-150 sputter-coater. Observations were performed and micrographs taken with a Cambridge Stereoscan S-360 SEM, at an accelerating voltage of $20 \mathrm{kV}$, at the Electron Microscopy Centre of the University of Ferrara (Italy). Adobe Photoshop 6.0 was used for adjustment of brightness and contrast of the photomicrographs and figure-labelling.

Chemicals. 3-aminobenzoic acid ethyl ester (methanesulphonate salt, MS-222) was supplied by Sigma Chemical Co., and dodecylbenzene-sulphonic acid sodium salt (LAS) from Fluka Chemie AG. All other chemicals used were of the highest reagent grade commercially available.

\section{RESULTS}

\section{Light microscopy}

Control fish

Each lamella of the olfactory rosettes appears to be covered on both sides by a pseudostratified columnar epithelium that encloses a stromal sheet (Fig. 1), and is separated into 2 regions: sensory and non-sensory. The sensory epithelium, located in the proximal (inner) third of each lamella, nearest to the median raphe, consists of various cell types (basal cells, spindleshaped receptor cells and cylindrical supporting cells). The non-sensory epithelium, covering the distal (outer) two-thirds of the lamella, also contains deep basal cells adjacent to other cell types (non-sensory ciliated cells, epidermal and goblet cells). Histologically, the sensory and non-sensory compartments are easily distinguishable by the position of the nuclei and appearance of the cilia, which are longer and more numerous in the latter (Fig. 2a,b).

\section{Treated fish}

The lamellae of olfactory rosettes of fish treated with $1.5 \mathrm{mg} \mathrm{l}^{-1}$ for 5 and $10 \mathrm{~d}$ were not different from those of controls. When the olfactory lamellae of fish treated for $15 \mathrm{~d}$ with the same dose were examined, the 2 epithelia (sensory and non-sensory) also appeared unaffected by LAS; the only difference from controls was the surface of the lamellae which, mainly in the sensory area, was not smooth, but had a slightly corrugated appearance.

In contrast, rosettes removed from fish treated with $3 \mathrm{mg} \mathrm{l}^{-1}$ LAS showed greater differences compared to controls: after $5 \mathrm{~d}$ of treatment, in the non-sensory region the cilia in the distal part of the lamella were more sparse (Fig. 3), and the alterations to the surface of the lamellar border affecting the sensory portion were more pronounced (Fig. 4). The damage was clearly identifiable after $15 \mathrm{~d}$ of treatment: the distal portion of the lamellae showed an almost complete loss of cilia, and the alterations to the lamellar border of the sensory epithelium were prominent.

\section{Scanning electron microscopy}

\section{Control fish}

The olfactory organ of Ictalurus melas, almost ellipsoidal in shape, consists of a series of lamellae radially arranged along the median raphe and forming a rosette-like structure (Fig. 5). The sensory epithelium, present on both sides of each lamella, is confined within a clearly defined area close to the raphe, extending a short distance beyond it (Fig. 6). The non-sensory epithelium, covering most of the lamellar surface, presents a dense coat of long cilia (Fig. 7). These latter are clearly visible in Fig. 8, which shows a preparation in which (owing to accidental fracture of the sample during critical-point drying) it is possible to see the cell bodies of the non-olfactory epithelium.

The sensory epithelium is characterized by a lower number of cilia per surface unit (Fig. 7), and consists of supporting cells provided with microvillous-like protrusions and 2 types of olfactory receptor cells (ORC) - ciliate (CRC) and microvillous (MRC). These 2 receptor-cell types terminate at the epithelial surface in an olfactory knob, which bears a tuft of cilia or microvilli, respectively (Fig. 9).

\section{Treated fish}

Both the non-sensory and sensory areas of the lamellae from specimens treated with $1.5 \mathrm{mg} \mathrm{l}^{-1}$ LAS for 5 and $10 \mathrm{~d}$ did not differ from those of controls. The lamellae obtained from fish treated with $1.5 \mathrm{mg} \mathrm{l}^{-1} \mathrm{LAS}$ for $15 \mathrm{~d}$ did not differ from controls as regards the sensory area, but an incipient thinning out of the long cilia could be observed in the non-sensory region, mainly affecting the third outer distal region of the lamella (Fig. 11a). This damage appeared more severe in fish subjected to $3 \mathrm{mg} \mathrm{l}^{-1}$ LAS for $5 \mathrm{~d}$ which showed large areas free of cilia. In the sensory area, the cilia of receptor cells appeared less numerous than in the controls (Fig. 10). The damage was more evident in fish treated with $3 \mathrm{mg} \mathrm{l}^{-1}$ for $15 \mathrm{~d}$, when the non-sensory surface of the lamellae bore only isolated tufts of cilia (Figs. 11b \& 12) and a marked reduction in the number of cilia of the 2 types of ORC was observed in the sen- 

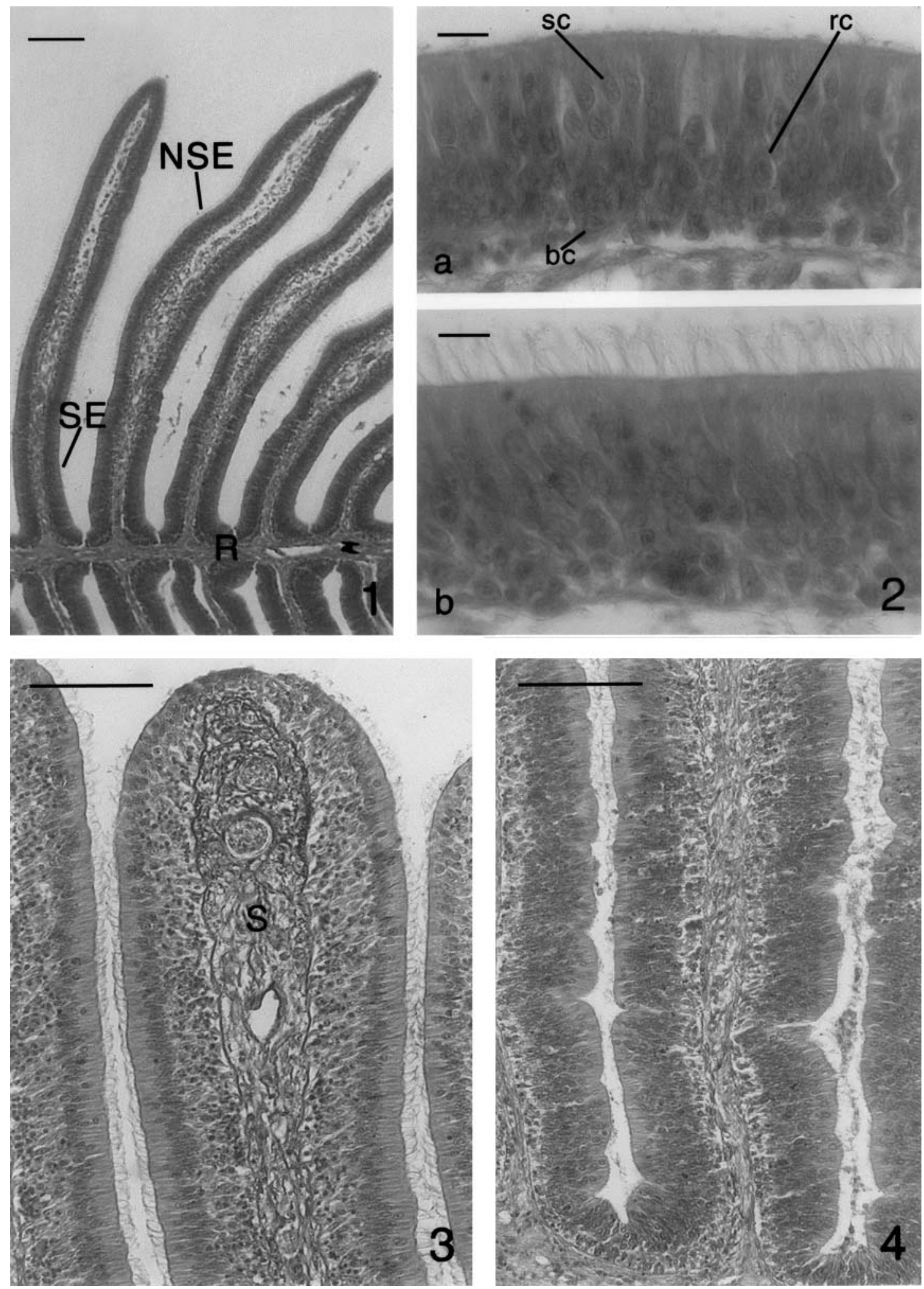

Figs. 1 to 4. Ictalurus melas; histological sections of olfactory rosette; H\&E staining. Fig. 1. Olfactory lamellae from control specimen; NSE: non-sensory epithelium; R: raphe; SE: sensory epithelium. Fig. 2. Sensory (a) and non-sensory (b) epithelia at higher magnification; bc: basal cell; rc: receptor cell; sc: supporting cell. Fig. 3. Distal part of 1 olfactory lamella from specimen exposed to $3 \mathrm{mg} \mathrm{l}^{-1}$ LAS for $5 \mathrm{~d}$; S: stroma; note thinning out of cilia of non-sensory cells at the apex of the lamella (cf. Fig. $2 \mathrm{~b}$ : control). Fig. 4. Proximal part of olfactory lamellae from specimen treated with $3 \mathrm{mg} \mathrm{l}^{-1}$ LAS for 5 d; note differences from corresponding portion (SE) in Fig. 1. (Scale bars $=1 \mu \mathrm{m}$ in Fig. 1, $10 \mu \mathrm{m}$ in Figs. 2-4) 

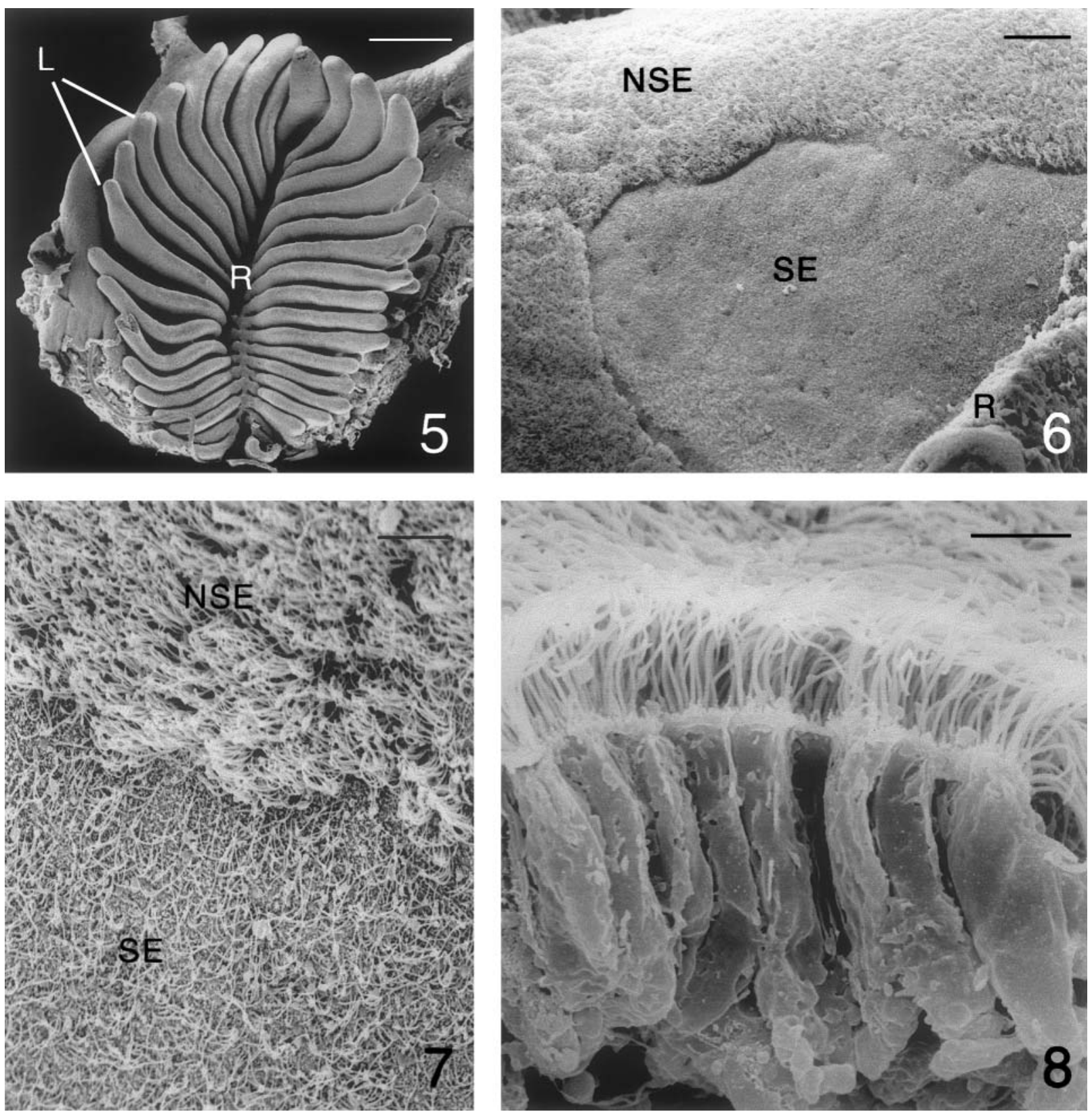

Figs. 5 to 8. Ictalurus melas. SEM of olfactory organ of control. Fig. 5 . Overall view; L: lamellae, R: raphe (scale bar $=0.5 \mathrm{~mm}$ ). Fig. 6. Isolated lamella showing non-sensory (NSE) and sensory (SE) epithelium confined to 2 clearly defined areas ( $\mathrm{scale}$ bar $=50 \mu \mathrm{m}$ ). Fig. 7. Non-sensory (NSE) and sensory (SE) epithelium at higher magnification (scale bar $=10 \mu \mathrm{m}$ ). Fig. 8. Detail of nonsensory epithelium showing cilia and cellular bodies (scale bar $=5 \mu \mathrm{m}$ )

sory area (Fig. 13). This alteration affected the CRC and MRC to the same extent. The loss of the long cilia of the CRC allowed the olfactory knobs to be observed: some knobs appeared completely bare, others still had a reduced number of cilia of normal length, and others had short cilia.

A considerable number of mucus particles were observed on the lamellae of the olfactory organs of fish treated with $3 \mathrm{mg} \mathrm{l}^{-1}$ for $15 \mathrm{~d}$ (Fig. 14a,b).

\section{DISCUSSION}

The anatomical arrangement of the lamellae inside the olfactory pits of fish allows toxic compounds to affect all the mucosal areas homogeneously.

The sensory epithelium of ictalurids lies in a welldefined and restricted area of each lamella; this makes it easier to evaluate differential damage of mucosa cells. The non-sensory epithelium, covered by a thick coat of 

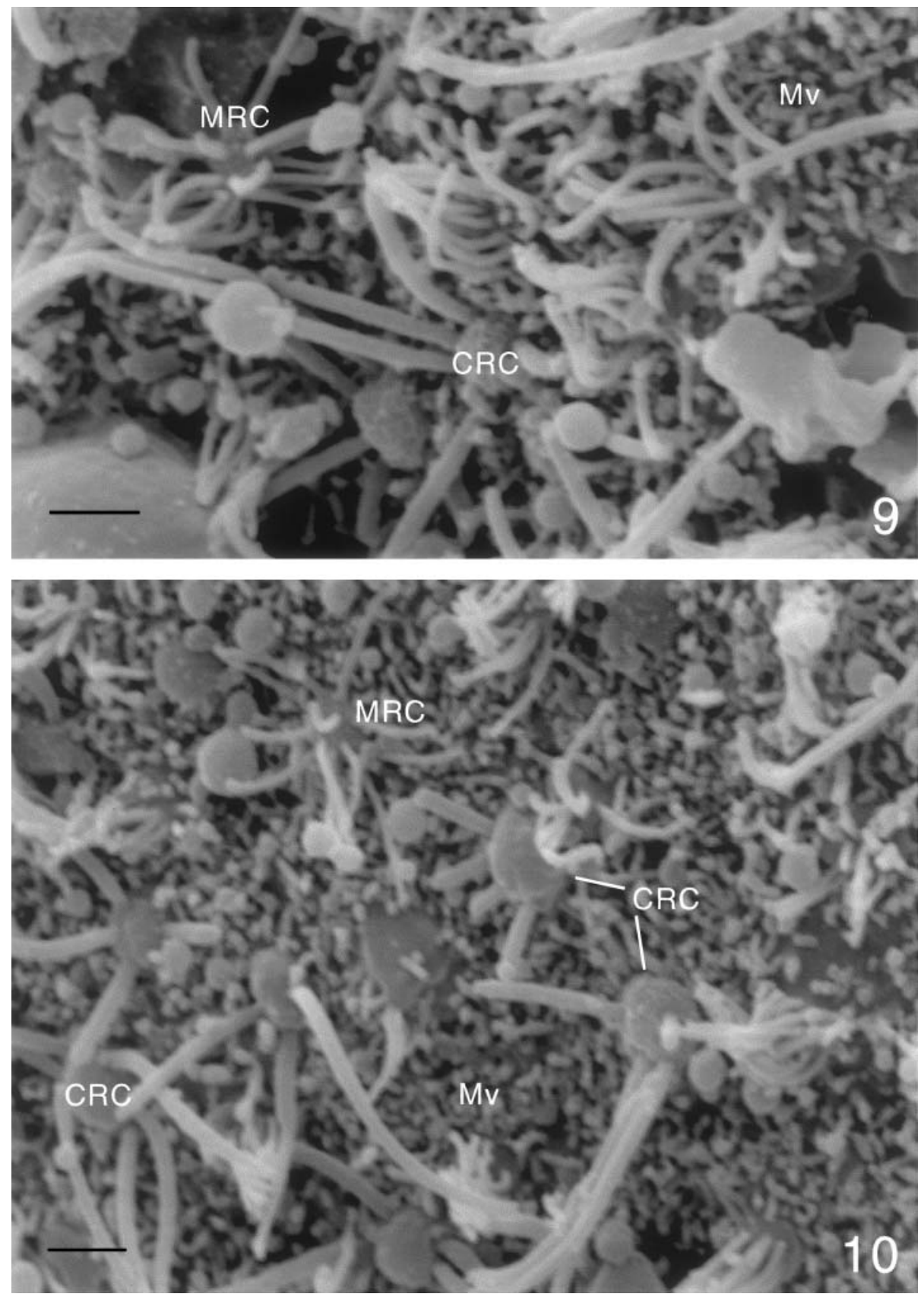

Figs. 9 \& 10. Ictalurus melas. SEM of sensory epithelium. Fig. 9. Epithelium from control specimen in which the 2 types of olfactory receptor cells (CRC: ciliate receptor cell; MRC: microvillous receptor cell) and the microvillous-like protrusions (Mv) of the supporting cells are visible. Fig. 10. Epithelium from specimen exposed to $3 \mathrm{mg} \mathrm{l}^{-1}$ LAS for $5 \mathrm{~d}$. (Both scale bars $\left.=1 \mu \mathrm{m}\right)$

cilia, generates a beating that forces the water and mucus towards the sensory area. It has been suggested that fish (such as Ictalurus spp.) with a high density of ciliated cells in the non-sensory area should be considered macrosmatic (Yamamoto \& Ueda 1978).

The olfactory epithelium of Ictalurus melas is characterized by 2 morphologically distinct types of ORC intermingled with supporting cells. Both the CRC and MRC are naked bipolar primary neurons, whose axons connect to the brain and whose dendrites are in contact with the environment, thus providing an easy port of entry to waterborne xenobiotics.

Our observations on control specimens agree with the present knowledge on the histology of the olfactory 

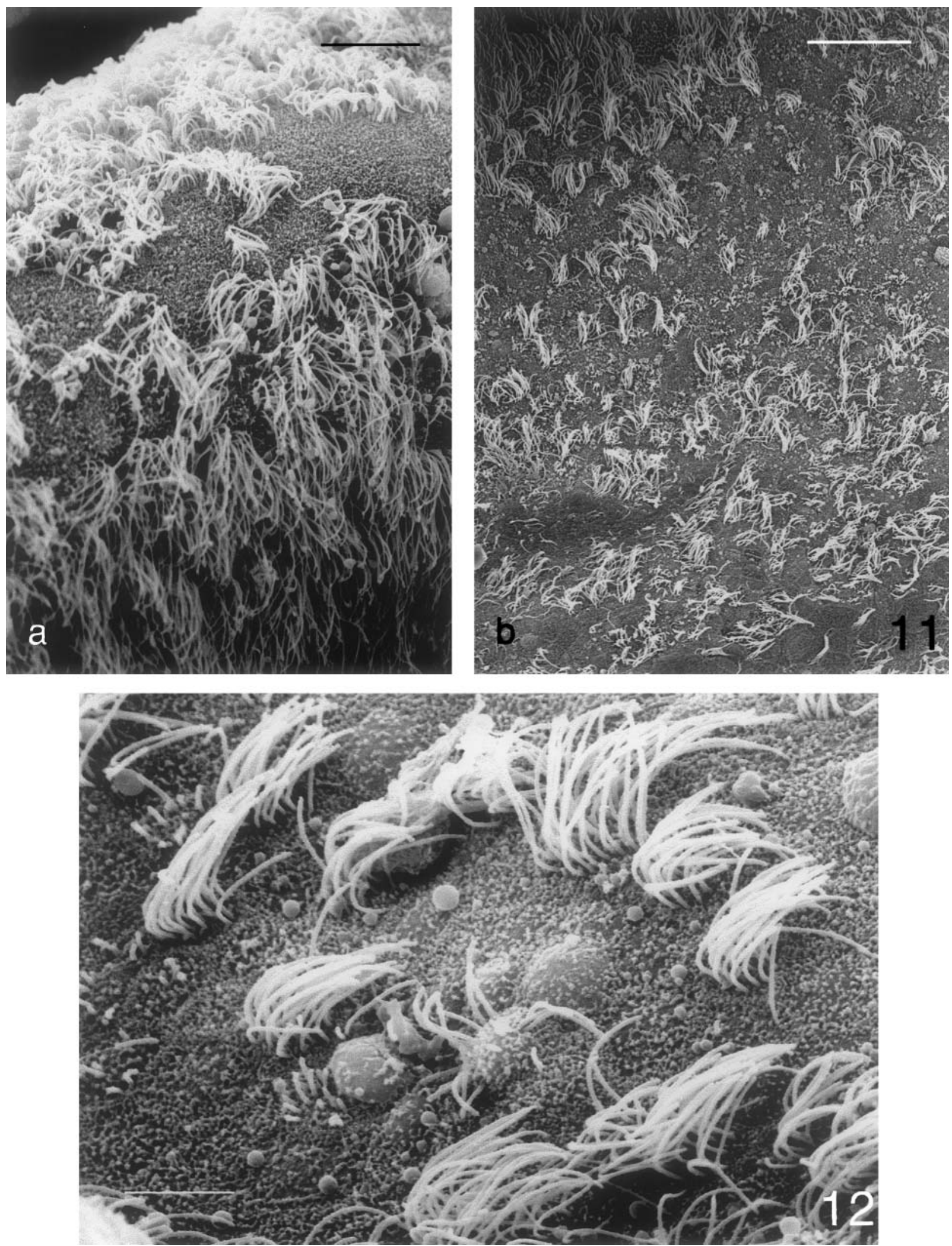

Figs. 11 \& 12. Ictalurus melas. SEM of non-sensory epithelium exposed to LAS. Fig. 11. (a) Epithelium from specimen treated with $1.5 \mathrm{mg} \mathrm{l}^{-1}$ for $15 \mathrm{~d}$ (scale bar $=10 \mu \mathrm{m}$ ); (b) Epithelium from specimen treated with $3 \mathrm{mg} \mathrm{l}^{-1}$ for $15 \mathrm{~d}(\mathrm{scale}$ bar $=25 \mu \mathrm{m})$. Fig. 12. Detail, at higher magnification, of epithelium from specimen treated with $3 \mathrm{mg} \mathrm{l}^{-1}$ for $15 \mathrm{~d}$ (scale bar $\left.=5 \mu \mathrm{m}\right)$ 

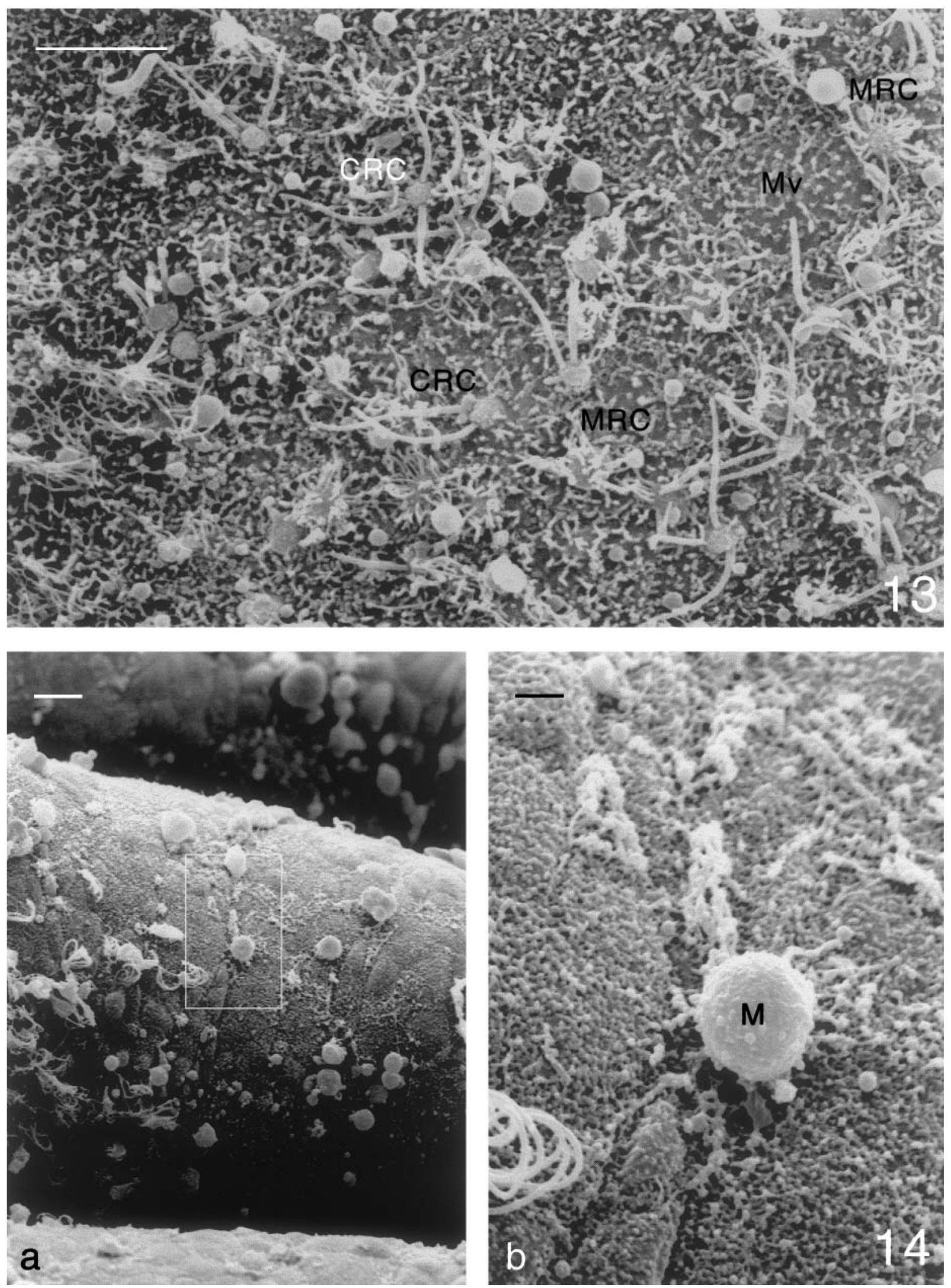

Figs. 13 \& 14. Ictalurus melas. Fig. 13. Sensory epithelium treated with $3 \mathrm{mg} \mathrm{l}^{-1} \mathrm{LAS}$ for $15 \mathrm{~d}$ SEM. CRC: ciliate receptor cell; MRC: microvillous receptor cell; Mv: microvilli of supporting cells (scale bar $=5 \mu \mathrm{m}$ ). Fig. 14. (a) SEM of lamellae of olfactory rosette after exposure to $3 \mathrm{mg} \mathrm{l} \mathrm{l}^{-1}$ LAS for $15 \mathrm{~d}$; note release of mucus droplets (scale bar $=10 \mu \mathrm{m}$ ). (b) Higher magnification of inset in (a) (scale bar $=2 \mu \mathrm{m}$ ) 
epithelium of ictalurid species (Cancalon 1978, Theisen et al. 1991, Morita \& Finger 1998). Our findings of damage of the non-sensory area agree with observations on the olfactory mucosa of rainbow trout Salmo gairdneri treated with aluminium and low $\mathrm{pH}$ (Klaprat et al. 1988). In contrast, Cancalon $(1982,1983)$, using $\mathrm{ZnSO}_{4}$ and Triton X-100 (a non-ionic detergent) for nasal irrigation in the channel catfish Ictalurus punctatus, described alterations exclusively in the sensory area.

Given that the epithelial organization in teleosts differs from species to species, varying degrees of resistance to the same treatment are observed. With regard to damage (and subsequent recovery), the route of toxicant administration may play a very important role. Chemicals introduced directly into the nostrils (even at high doses) are in contact with the mucosa for a very short time, and are quickly removed, since the water flow within these cavities is fast and continuous when the fish is swimming. Conversely, when the toxicant is present in the water, prolonged contact with the olfactory epithelium occurs.

We observed that $1.5 \mathrm{mg} \mathrm{l}^{-1}$ of LAS did not cause significant histological or ultrastructural modifications. This is in agreement with the observations of Olsén \& Höglund (1985), who did not find any damage to the cell surface of the olfactory epithelium of artic charr, Salvelinus alpinus, exposed to sublethal doses $\left(2 \mathrm{mg} \mathrm{l}^{-1}\right)$ of sodium alkylbenzene sulphonate for $4 \mathrm{~d}$.

In our experiments, $3 \mathrm{mg} \mathrm{l}^{-1}$ of LAS produced evident modifications, progressive throughout the experiment. The damage mainly affected the superficial part of the lamellae: the number of cilia of epithelium progressively decreased in both the sensory and non-sensory areas, while the basal cells, which do not reach the free surface, were not affected. Other authors who used sublethal doses of detergents also described prevailing superficial damage. Even if the damage affects only the ORC cellular projections, an olfactory neurophysiological impairment can be hypothesized, since the membranes covering the ORC cilia and microvilli are one of the most important olfactory recognition sites (for review see Schild \& Restrepo 1998). Many studies have demonstrated that morphological alterations induced by several aquatic contaminants (generally heavy metals and pesticides, but also detergents) are accompanied by reduced electric activity, recordable as electroolfactogram (EOG) or electroencephalogram (EEG), in the ORC and olfactory bulb respectively (Bardach et al. 1965, Sutterlin et al. 1971, Baatrup et al. 1990, Hansen et al. 1999b). Other studies have confirmed the relationship between the impairment of olfactory discrimination and behaviour (Rehnberg \& Schreck 1986, Hidaka \& Tatsukawa 1989, Saglio \& Trijasse 1998, Hansen et al. 1999a). Detergents at sublethal doses are in fact able to affect feeding behav- iour, conspecific attraction, and locomotory activity (Bardach et al. 1965, Olsén \& Höglund 1985, Barbieri et al. 1998).

The mucus covering the olfactory lamellae constitutes an important medium in which the odorants are diffused. An increased mucus production is among the early responses of fishes to environmental stress; it has been observed, for example, on the skin and gills of fishes exposed to sublethal concentrations of LAS (Pohla-Gubo \& Adam 1982, Zaccone et al. 1985a,b). Using SEM, we observed, in individuals treated with $3 \mathrm{mg} \mathrm{l}^{-1}$ LAS, an abundance of spherical particles on the olfactory lamellae, interpreted as mucus droplets on the basis of their size and ultrastructural appearance, and comparable to the mucus droplets illustrated in the studies of other authors (e.g. Olsén 1993). At present, we have no data on the changes in the number and size of the goblet cells, nor histochemical stainings, and therefore we are not certain that these spherical particles represent an increased mucus release, although similar particles were observed by SEM in the deciliated olfactory mucosa of the freshwater teleost Trichomycterus brasiliensis following treatment with mercuric chloride by Oliveira Ribeiro et al. (1995).

In conclusion, our results revealed evident damage to the epithelium covering the lamellae consequent to treatment with $\mathrm{mg} \mathrm{l}^{-1}$ LAS for $15 \mathrm{~d}$, chiefly affecting the cilia of the sensory and non-sensory cells. Further ultrastructural studies (TEM) would clarify if the loss of the cilia is caused by an actual loss of ciliated cells. Since the damage is superficial, and the olfactory epithelium exhibits remarkable neural plasticity, this process could theoretically be reversible. Even if the damage were transitory, the ecological importance of exposure to pollutants capable of affecting chemoreception is not to be underestimated. Many toxicants are able to cause alterations in behaviour, since the fishes utilize chemosensory information in order to select favourable conditions for survival. Even a brief and transitory blockade in olfactory perception could be fatal to these fishes, as it would make them more vulnerable to predation and disease, or affect their reproduction. The environmental concentrations of LAS in rivers receiving activated sludge and treated municipal effluents range from 0.0008 to $3.3 \mathrm{mg} \mathrm{l}^{-1}$ (Lewis 1991), a range including the doses employed in this study.

Acknowledgements. The authors are very grateful to Professor Luigi Abelli for his helpful suggestions and critical reading of the manuscript. They wish to thank also Dr. Maria Rita Bovolenta of the Electron Microscopic Center of Ferrara University for competent technical assistance; Mr. Sergio Borghi for excellent photographic assistance in the preparation of figures, and Mrs. Linda Mairi Bruce for English revision. This research was supported by a grant from Ferrara University. 


\section{LITERATURE CITED}

Abogadie FC, Bruch RC, Farbman AI (1995) G-protein subunits expressed in catfish olfactory receptor neurons. Chem Senses 20:199-207

Arnold H, Pluta HJ, Braunbeck T (1996) Cytological alterations in the liver of rainbow trout Oncorhynchus mykiss after prolonged exposure to low concentrations of waterborne endosulfan. Dis Aquat Org 25:39-52

Baatrup E, Døving KB (1990) Histochemical demonstration of mercury in the olfactory system of salmon (Salmo salar L.) following treatments with dietary methylmercuric chloride and dissolved mercuric chloride. Ecotoxicol Environ Saf 20:277-289

Baatrup E, Døving KB, Winberg S (1990) Differential effects of mercurial compounds on the electroolfactogram (EOG) of salmon (Salmo salar L.). Ecotoxicol Environ Saf 20: 269-276

Barbieri E, Ngan PV, Gomes V (1998) The effect of SDS, sodium dodecyl sulfate, on the metabolism and swimming capacity of Cyprinus carpio. Rev Bras Biol 58:263-271

Bardach JE, Fujiya M, Holl A (1965) Detergents: effects on the chemical senses of the fish Ictalurus natalis (Le Sueur). Science 148:1605-1607

Braunbeck T, Volkl A (1991) Induction of biotransformation in the liver of eel (Anguilla anguilla L.) by sublethal exposure to dinitro-o-cresol: an ultrastructural and biochemical study. Ecotoxicol Environ Saf 21:109-127

Braunbeck TA, Teh SJ, Lester SM, Hinton DE (1992) Ultrastructural alterations in liver of medaka (Oryzias latipes) exposed to diethylnitrosamine. Toxicol Pathol 20: 179-196

Cancalon P (1978) Isolation and characterization of the olfactory epithelial cells of the catfish. Chem Senses 3: 381-396

Cancalon P (1982) Degeneration and regeneration of the olfactory cells induced by $\mathrm{ZnSO}_{4}$ and other chemicals. Tissue Cell 14:717-733

Cancalon P (1983) Influence of detergent on the catfish olfactory mucosa. Tissue Cell 15:245-258

Caprio J, Raderman-Little R (1978) Scanning electron microscopy of the channel catfish olfactory lamellae. Tissue Cell 10:1-9

Døving KB (1986) Functional properties of the fish olfactory system. In: Autrum H, Ottoson D, Perl ER, Schmidt RF, Shimazu H, Willis WD (eds) Progress in sensory physiology, Vol 6. Springer-Verlag, Berlin, p 39-104

Gardner GR (1975) Chemically induced lesions in estuarine or marine teleosts. In: Ribelin WE, Migaki G (eds) The pathology of fishes. The University of Wisconsin Press, Madison, p 657-693

Gard-Terech A, Palla GC (1986) Comparative kinetics study of the evolution of freshwater aquatic toxicity and biodegradability of linear and branched alkylbenzene sulphonates. Ecotoxicol Environ Saf 12:127-140

Garg TK, Mittal AK (1993) Observations on the function of mucous cells in the epidermis of the catfish Clarias batrachus exposed to sodium dodecyl sulfate. Biomed Environ Sci 6:119-133

Gledhill WE (1974) Linear alkylbenzene sulphonate: biodegradation and aquatic interactions. Adv Appl Microbiol $17: 265-293$

Goksoyr A, Husoy AM (1998) Immunochemical approaches to studies of CYP1A localization and induction by xenobiotics in fish. EXS (Basel) 86:165-202

Goulding EH, Ngai J, Kramer R, Colicos S, Axel R, Siegelbaum S, Chess A (1992) Molecular cloning and single- channel properties of the cyclic nucleotide-gated channel from catfish olfactory neurons. Neuron 8:45-58

Hansen JA, Marr JCA, Lipton J, Cacela D, Bergman HL (1999a) Differences in neurobehavioral responses of chinook salmon (Oncorhynchus tshawytscha) and rainbow trout (Oncorhynchus mykiss) exposed to copper and cobalt: behavioral avoidance. Environ Toxicol Chem 18:1972-1978

Hansen JA, Rose JD, Jenkins RA, Gerow KG, Bergman HL (1999b) Chinook salmon (Oncorhynchus tshawytscha) and rainbow trout (Oncorhynchus mykiss) exposed to copper: neurophysiological and histological effects on the olfactory system. Environ Toxicol Chem 18:1979-1991

Hara TJ (1994) Olfaction and gustation in fish: an overview. Acta Physiol Scand 152:207-217

Hawkins WE, Walker WW, Overstreet RM, Lytle TF, Lytle JS (1990) Carcinogenic effect of some polycyclic aromatic hydrocarbons on the Japanese medaka and guppy in waterborne exposures. Sci Total Environ 94:155-167

Hidaka H, Tatsukawa R (1989) Avoidance by olfaction in a fish medaka (Oryzias latipes), to aquatic contaminants. Environ Pollut 56:299-309

Hinton DE, Couch JA (1998) Architectural pattern tissue and cellular morphology in livers of fishes: relationship to experimentally-induced neoplastic responses. EXS (Basel) 86:141-164

Julliard AK, Saucier D, Astic L (1993) Effects of chronic lowlevel copper exposure on ultrastructure of the olfactory system in rainbow trout (Oncorhynchus mykiss). Histol Histopathol 8:655-672

Julliard AK, Saucier D, Astic L (1996) Time-course of apoptosis in the olfactory epithelium of rainbow trout exposed to a low copper level. Tissue Cell 28:367-377

Klaprat DA, Brown SB, Hara TJ (1988) The effect of low pH and aluminum on the olfactory organ of rainbow trout, Salmo gairdneri. Environ Biol Fish 22:69-77

Klaunig JE, Lipsky MM, Trump BF, Hinton DE (1979) Biochemical and ultrastructural changes in teleost liver following subacute exposure to PCB. J Environ Pathol Toxicol 2:953-963

Lester SM, Braunbeck TA, Teh SJ, Stegeman JJ, Miller MR, Hinton DE (1993) Hepatic cellular distribution of cytochrome P-450 1A1 in rainbow trout (Oncorhynchus mykiss): an immunohisto-and cytochemical study. Cancer Res 53:3700-3706

Lewis MA (1991) Chronic and sublethal toxicities of surfactants to aquatic animals: a review and risk assessment. Water Res 25:101-113

Mallatt J (1985) Fish gill structural changes induced by toxicants and other irritants: a statistical review. Can J Fish Aquat Sci 42:630-648

Misra V, Lal H, Chawla G, Viswanathan PN (1985) Pathomorphological changes in gills of fish fingerlings (Cirrhina mrigala) by linear alkyl benzene sulphonate. Ecotoxicol Environ Saf 10:302-308

Mittal AK, Garg TK (1994) Effect of an anionic detergentsodium dodecyl sulphate exposure on club cells in the epidermis of Clarias batrachus. J Fish Biol 44:857-875

Monod G, Saucier D, Perdu-Durand E, Diallo M, Cravedi JP, Astic L (1995) Catalytic and immunocytochemical detection of xenobiotic metabolizing enzymes in the olfactory organ of rainbow trout (Oncorynchus mykiss). Mar Environ Res 39:39-43

Morita Y, Finger TE (1998) Differential projections of ciliated and microvillous olfactory receptor cells in the catfish, Ictalurus punctatus. J Comp Neurol 398:539-550

Oliveira Ribeiro CA, Fernandes LM, Carvalho CS, Cardoso RI, Turcatti NM (1995) Acute effects of mercuric 
chloride on the olfactory epithelium of Trichomycterus brasiliensis. Ecotoxicol Environ Saf 31:104-109

Olsén KH (1993) Development of the olfactory organ of Artic charr, Salvelinus alpinus (L.) (Teleostei, Salmonidae). Can J Zool 71:1973-1984

Olsén KH, Höglund LB (1985) Reduction by a surfactant of olfactory mediated attraction between juveniles of arctic charr, Salvelinus alpinus (L.). Aquat Toxicol (Amst) 6:57-69

Pareschi C, Ferretti E, Zeni C, Stagni Caligiuri A, Vignocchi B, Biondi C (1997) Effects of exposure to linear alkylbenzene sulphonate on cAMP levels in Ictalurus sp. olfactory and gustatory tissues. Comp Biochem Physiol C116:11-16

Pohla-Gubo G, Adam H (1982) Der Einfluß des anionaktiven Tensids Na-alkyl-benzol-sulphonat (LAS) auf die KopfEpidermis juveniler Regenbogenforellen (Salmo gairdneri Richardson). Zool Anz 209:97-110

Rehnberg BC, Schreck CB (1986) Acute metal toxicology of olfaction in coho salmon: behavior, receptors, and odor metal complexation. Bull Environ Contam Toxicol 36:579-586

Restrepo D, Boekhoff I, Breer H (1993) Rapid kinetic measurements of second messenger formation in olfactory cilia from channel catfish. Am J Physiol 264:C906-C911

Ribelles A, Carrasco C, Rosety M (1995a) Morphological and histochemical changes caused by sodium dodecyl sulphate in the gills of gilthead (Sparus aurata L.). Eur J Histochem 39:141-148

Ribelles A, Carrasco MC, Rosety M, Aldana M (1995b) Morphological and histochemical changes in the liver and pancreas of gilthead, Sparus aurata L., induced by acute action of the anionic detergent, sodium dodecyl sulphate. Histol Histopathol 10:781-787

Ribelles A, Carrasco MC, Rosety M, Aldana M (1995c) A histochemical study of the biological effects of sodium dodecyl sulphate on the intestine of the gilthead seabream, Sparus aurata L. Ecotoxicol Environ Saf 32:131-138

Rosety M, Ribelles A, Carrasco C (1997) A morphological study in the kidney and spleen of gilthead, Sparus aurata L., caused by sodium dodecyl sulphate. Histol Histopathol 12:925-929

Roy D (1988a) Toxicity of an anionic detergent, dodecylbenzene sodium sulphonate, to a freshwaterfish, Rita rita: determination of $\mathrm{LC}_{50}$ values by different methods. Ecotoxicol Environ Saf 15:186-194

Roy D (1988b) Statistical analysis of anionic detergentinduced changes in the goblet mucous cells of opercular epidermis and gill epithelium of Rita rita (Ham.) (Bagridae: Pisces). Ecotoxicol Environ Saf 15:260-271

Saglio P, Trijasse S (1998) Behavioral responses to atrazine and diuron in goldfish. Arch Environ Contam Toxicol 35: $484-491$

Sarasquete C, Segner H (2000) Cytochrome P4501A (CYP1A) in teleostean fishes. A review of immunohistochemical studies. Sci Total Environ 247:313-332

Editorial responsibility: Thomas Braunbeck, Heidelberg, Germany
Saucier D, Julliard AK, Monod G, de Bréchard H, Astic L (1999) CYP1A1 immunolocalization in the olfactory organ of rainbow trout and its possible induction by B-naphtoflavone: analysis in adults and embryos around hatching. Fish Physiol Biochem 21:179-192

Schild D, Restrepo D (1998) Transduction mechanisms in vertebrate olfactory receptor cells. Physiol Rev 78:429-466

Schoenkaes U (1998) LAS - a modern classic surfactant. Chim Oggi (Chem Today) 16:9-13

Scott MJ, Jones MN (2000) The biodegradation of surfactants in the environment. Biochim Biophys Acta 1508:235-251

Smolowitz RM, Schulz ME, Stegeman JJ (1992) Cytochrome $\mathrm{P} 4501 \mathrm{~A}$ induction in tissue, including olfactory epithelium, of topminnows (Poeciliopsis sp.) by waterborne benzopyrene. Carcinogenesis (Lond) 13:2395-2402

Sutterlin A, Sutterlin N, Rand S (1971) The influence of synthetic surfactants on the functional properties of the olfactory epithelium of Atlantic salmon. Fish Res Board Can Tech Rep 287:1-8

Theisen B, Zeiske E, Silver WL, Marui T, Caprio J (1991) Morphological and physiological studies on the olfactory organ of the striped eel catfish, Plotosus lineatus. Mar Biol 110:127-135

Valentincic TB, Caprio J (1994) Chemical and visual control of feeding and escape behaviors in the channel catfish Ictalurus punctatus. Physiol Behav 55:845-855

Yamamoto M, Ueda K (1978) Comparative morphology of fish olfactory epithelium. VI. Siluriformes. Zool Mag (Tokyo) 87:254-261

Zaccone G, Lo Cascio P, Fasulo S, Licata A (1985a) The effect of an anionic detergent on complex carbohydrates and enzyme activities in the epidermis of the catfish Heteropneustes fossilis (Bloch). Histochem J 17:453-466

Zaccone G, Fasulo S, Lo Cascio P, Licata A (1985b) Patterns of enzyme activities in the gills of the catfish Heteropneustes fossilis (Bloch) exposed to the anion-active detergent sodium alkylbenzenesulphonate (LAS). Histochemistry 82:341-343

Zeiske E, Theisen B, Breucker H (1994) The olfactory organ of the hardhead sea catfish, Arius felis (L.): gross morphology and fine structure. Acta Zool (Stockh) 75:115-123

Zeni C, Stagni Caligiuri A (1992) Morphological and ultrastructural changes induced by an anionic detergent on Ictalurus species barbel taste buds. Microbios 69:41-52

Zeni C, Stagni Caligiuri A, Bovolenta MR (1995) Damage and recovery of Ictalurus sp. barbel taste buds exposed to sublethal concentrations of an anionic detergent. Aquat Toxicol (Amst) 31:113-123

Zeni C, Bovolenta MR, Stagni A (2002) Occurrence of echinocytosis in circulating RBC of black bullhead, Ictalurus melas Rafinesque, following exposure to an anionic detergent at sublethal concentrations. Aquat Toxicol (Amst) 57:217-224

Submitted: August 10, 2001; Accepted: February 28, 2002 Proofs received from author(s): July 15, 2002 